\title{
Показники крові та діяльності серцево-судинної системи в працівників шкідливих професій
}

\author{
Ольга Покотило ${ }^{1}$, Тетяна Поручинська ${ }^{1}$, Оксана Стасюк $^{2}$ \\ ${ }^{1}$ Східноєвропейський національний університет імені Лесі Українки, Луцьк, Україна \\ ${ }^{2}$ КНП «Тернопільська міська комунальна лікарня № 2», Тернопіль, Україна \\ Адреса для листування: olka.pokotylo@gmail.com
}

Отримано: 21.05.19; прийнято до друку: 14.06.19; опубліковано: 28.06.2019

\begin{abstract}
Резюме. Оцінка загальних показників крові й серцевої діяльності серця $є$ важливою у визначенні стану досліджуваних, у т. ч. працівників шкідливих професій. Мета роботи - вивчити загальні дані крові та серця в працівників шкідливих професій. У досліджені брали участь 43 особи, які проходили обстеження в межах періодичного медичного огляду. Це були працівники восьми різних професій (водійрятувальник - $17 \%$, електрогазозварювальник - $10 \%$, електромонтер - $12 \%$, кранівник - $15 \%$, лаборант - $15 \%$, оператор АЗС - $12 \%$, оператор котельні - $7 \%$, слюсар - $12 \%$ ). Роботу серця оцінювали за параметрами електрокардіограми. Запис ЕКГ здійснювали, застосовуючи електрокардіограф ECG 300G у відділені функціональної діагностики, визначення загальних показників крові відбувалося за загальними методиками на базі клініко-діагностичної лабораторії Тернопільської міської комунальної лікарні № 2. Аналізували показники загального аналізу крові та характеристики ЕКГ (кут відхилення ЕВС, частоту серцевих скорочень, коливання інтервалу RR й інтервали: RR, PQ, QT, зубець P, комплекс QRS i систолічний показник). Показники загального аналізу крові в більшості досліджуваних перебували в межах норми. Виявили відмінності показників гемоглобіну, еритроцитів, сегментоядерних клітин i моноцитів у працівників різних професій. Порівняння показників ЕКГ засвідчило відмінності між величиною кута ЕВС, який мав значні відхилення від норми в електромонтерів, операторів котелень і слюсарів. Також за межі норми виходили показники тривалості інтервалу RR в електромонтерів, лаборантів й операторів АЗС. Незначні відхилення виявлено в значеннях зубця P і комплексу QRS.
\end{abstract}

Ключові слова: шкідливі професії, серцево-судинна система, електрокардіограма, лабораторний аналіз.

\section{Blood Values and Cardiovascular System Activity Indices Characteristic of the Workers of Unhealthy Occupations}

\author{
Olga Pokotylo ${ }^{1}$, Tetiana Poruchynska ${ }^{1}$, Oksana Stasiuk ${ }^{2}$ \\ ${ }^{1}$ Lesia Ukrainka Eastern European National University, Lutsk, Ukraine \\ ${ }^{2} \mathrm{KNE}$ «Ternopil City Communal Hospital № 2», Ternopil, Ukraine \\ Correspondence: olka.pokotylo@gmail.com
}

\begin{abstract}
Comparison and evaluation of general blood parameters and electrocardiogram is important for determining health condition of the persons under investigation, including workers of unhealthy occupations. Therefore, the question arises about the way harmful working conditions affect the state of cardiovascular system. The purpose of the article is to study general blood parameters and heart electrocardiograms of the employees working in unhealthy conditions. The investigation involved 43 workers belonging to 8 different professions (rescue driver $-17 \%$, electric welder $-10 \%$, electrician $-12 \%$, crane operator $-15 \%$, laboratory assistant $-15 \%$, fuel station operator $-12 \%$, boiler operator $-7 \%$, locksmith $-12 \%$ ), who were examined during medical check. ECG recording was performed using ECG 300G electrocardiograph in the
\end{abstract}


department of functional diagnostics, the calculation of general blood parameters was done according to the general methods in the clinical diagnostic laboratory. All procedures were carried out on the basis of Ternopil city communal hospital № 2. Such parameters of the general blood analysis as hemoglobin, red blood cells, color index, reticulocytes, platelets, leukocytes, ESR, myelocytes, metamyelocytes, rod nuclear cells, segmentated cells, eosinophils, basophils, lymphocytes, monocytes, plasma cells - have been analyzed. The analysis of ECG characteristics, and namely - EOS deviation angle, heart rate, RR interval variations and RR, PQ, QT, P wave, QRS complex and systolic rate - has also been done. The comparison of the mean values of the total blood count revealed differences between representatives of different occupations, the greatest number of statistically significant differences was observed when comparing hemoglobin and red blood cells parameters. Differences were traced between the number of segmental cells and monocytes, the values of lymphocytes were within the normal limits, except for rescue drivers whose lymphocytes value indicators went beyond the norm. Comparison of ECG indicators revealed differences between the magnitude of the EOS angle, which had significant deviations from the standards among electricians, boiler operators and locksmiths. Indicators of the RR interval duration among electricians, laboratory assistants and operators of fuel stations are also over the limit. Minor differences are also evident in the values of the $\mathrm{P}$ wave and the QRS complex, and minor deviations from the standards can be observed as well.

Key words: unhealthy occupations, cardiovascular system, electrocardiogram (ECG), laboratory analysis.

\section{Вступ}

Здоров'я людини значною мірою залежить від екологічної ситуації місця ії проживання та праці. Пов'язано це 3 погіршенням стану навколишнього середовища й прогресуючим техногенним навантаженням. Підвищений уміст хімічних сполук у середовищі спричиняе виникнення хвороботворних станів, розвиток серцево-судинних захворювань [1].

Проблема стану здоров'я населення України нині дуже актуальна. Останнім часом відбувається інтенсивне забруднення навколишнього середовища, що спричинене збільшенням кількості автомобільних викидів, відходів від великих промислових підприємств і побутового сміття, яке не підлягає переробці [2].

Можливість адаптації індивіда в реальних умовах утворюе антропоекологічне напруження. Чинниками напруження виступають виробничі умови, обмеження рухової активності, нераціональне харчування, високий рівень забруднення повітря, грунту й води, побутові умови тощо. Саме до таких чинників і належить робота на підприємствах зі шкідливими умовами праці [3]. За результатами спостережень ВОO3, Україна є першою в Свропі та другою у світі за рейтингом смертності від серцево-судинних захворювань. 3 усієї кількості смертей 67 \% саме через ці проблеми [4].

Система кровообігу $є$ відповідальною за адаптацію до більшості факторів зовнішнього середовища, вона $є$ індикатором адаптаційних реакцій усього організму. Недостатність часу на відновлення механізмів i часта зміна параметрів серцево-судинної системи свідчать про виникнення патологічних процесів внутрішніх органів [5].

Шкідливі умови праці характеризується значною зміною гігієнічних норм. Вони спроможні несприятливо впливати на організм працівника й можуть слугувати причиною виникнення хронічних паталогій із тимчасовою втратою працездатності. Усі представлені в роботі досліджувані є працівниками шкідливих професій згідно 3 наказом Міністерства охорони здоров'я України від 21 травні 2007 р. № 246 «Про порядок проведення медичних оглядів працівників певних категорій» [6].

Механізми впливу шкідливих чинників виробництва на стан системи крові та серцевосудинну систему є досить складними. Серцевосудинна система одна 3 перших реагує на будьякі зовнішні зміни. Особливо негативний вплив на серцеву систему мають такі умови праці, як надмірні фізичні навантаження, постійні стреси на роботі, робота в нічну зміну, сильні виробничі шуми, вібрація від роботи механізмів, підвищена температура повітря у виробничому приміщенні, гіподинамія. Ці умови можуть спричиняти серйозні функціональні розлади серцево-судинної системи. Особливо шкідливою для роботи серця є виробнича вібрація. Частота власних коливань людського організму перебуває в межах 5-9 Гц. Якщо на організм діє виробнича вібрація 3 такою самою частотою, виникає резонанс. Наслідками таких порушень може бути навіть повна зупинка роботи серця [7].

Під час виконання фізичної роботи кров посилено припливає до м'язів, забезпечуючи надходження кисню й видалення продуктів окислення. Цьому сприяє активна робота серця та органів дихання. Тому частота серцевих скорочень під час виконання важких робіт досить суттєво зростає практично двічі [8].

Основним способом надходження промислових шкідливих речовин в організм людини є дихальні шляхи, через які шкідливі речовини потрапляють у кров. Природа цих 
речовин може бути різноманітною, проте переважно вони хімічного походження. Їх надмірна кількість позначається на показниках загального аналізу крові [8].

3 огляду на вищесказане можемо зробити висновок, що вивчення впливу шкідливих умов праці на серцево-судину систему й показники крові є досить актуальним.

Мета роботи - вивчити загальні показники крові та електрокардіограми серця в працівників шкідливих професій.

\section{Матеріали й методи}

Досліджували показники загального налізу крові та електрокардіограми 43 осіб обох статей (21\% жінок і 79 \% чоловіків), середній вік досліджуваних - 36,35 $\pm 1,94$ роки. Усі пацієнти були працівниками різних професій, котрі піддаються шкідливому впливу виробництва, а саме: водіями-рятувальниками (17\%), електрогазозварювальниками (10\%), електромонтерами (12\%), кранівниками (15\%), лаборантами (клінічні й біохімічні) (15\%), операторами АЗС (12\%), операторами котельні (7\%), слюсарями (12\%). Усі вони проходили обстеження в межах періодичних медичних оглядів, які проводилися на базі Тернопільської міської комунальної лікарні № 2. Реєстрацію ЕКГ здійснювали на електрокардіографі ECG 300G за загальноприйнятою методикою ЕКГ [9].

Показники крові досліджувалися із застосуванням стандартних методик. Визначення кількості гемоглобіну (Нb) здійснювали за допомогою калориметричного методу Салі. Підрахунок формених елементів крові - за допомогою камери Горяєва. Обчислення кольорового показника проводили, використовуючи порівняння $\mathrm{Hb}$ у крові та норму 3 кількістю еритроцитів у крові й нормою. Ретикулоцити підраховували за допомогою фарбування мазка крові. Лейкоцитарну формулу визначали за допомогою фарбування Романовського-Гімза. Визначення швидкості осідання еритроцитів (ШОЕ) здійснювали за допомогою методу Панченкова [10].

Статистичну обробку даних виконували за допомогою програми MS Excel 2010. Різницю між двома середніми величинами вважали достовірною при значенні $\mathrm{p} \leq 0,05$.

\section{Результати та обговорення}

Дослідження показників, отриманих під час загального аналізу крові, значних відхилень від норми в працівників шкідливих професій не виявило. $\mathrm{У}$ результаті порівняння середніх величин установлені деякі статистично достовірні відмінності показників крові у представників різних професій, однак при цьому ці дані переважно перебували в межах фізіологічної норми. Виявлені незначні відхилення в показнику ШОЕ лаборантів $(15,5 \pm 3,39$ мм/год), який був найвищим серед представників усіх досліджуваних професій; найнижчий цей показник у водіїв-рятувальників $(4,57 \pm 1,4$ мм/год) $(\mathrm{p} \leq 0,05)$. Отримані результати свідчать, що в досліджуваних на момент обстеження немає хронічних чи гострих захворювань, які б викликали істотні зміни показників крові.

Частота серцевих скорочень (ЧСС) досліджуваних не виходила за межі фізіологічної норми; порівняльний аналіз не виявив статистичних відмінностей між результатами ЧСС у представників різних професій $(\mathrm{p} \geq 0,05)$.

Дослідження електричної активності серцевого м'яза засвідчило деякі особливості в працівників шкідливих професій. Зокрема, показник електричної осі серця (ЕВС) у слюсарів $\left(13,20 \pm 22,77^{\circ}\right)$ та електромонтерів $\left(11,00 \pm 12,41^{\circ}\right)$ був істотно нижчим $(p \leq 0,05)$, порівняно 3 працівниками інших професій; найвище значення $\mathrm{EBC}$ зареєстровано в операторів котельні $\left(85,67 \pm 10,47^{\circ}\right)$ (рис. 1).

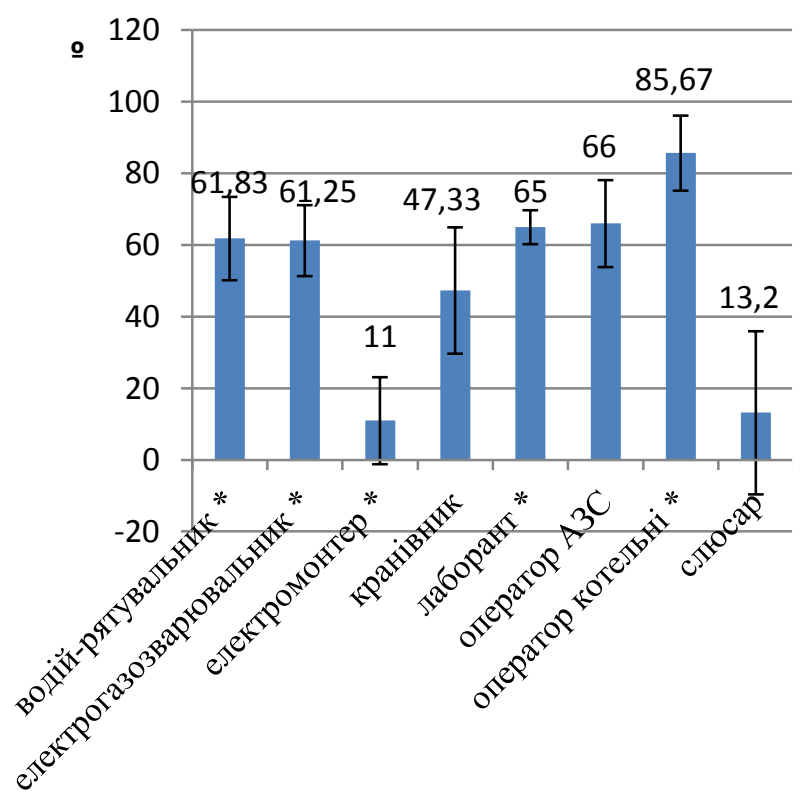

Рис. 1. Середні показники кута відхилення EBC ( $\left.{ }^{\circ}\right)$

Примітка до рис. 1-4. * - значуща відмінність показників, $p \leq 0,05$.

Коливання тривалості інтервалу RR було найвищим в електрогазозварювальників 

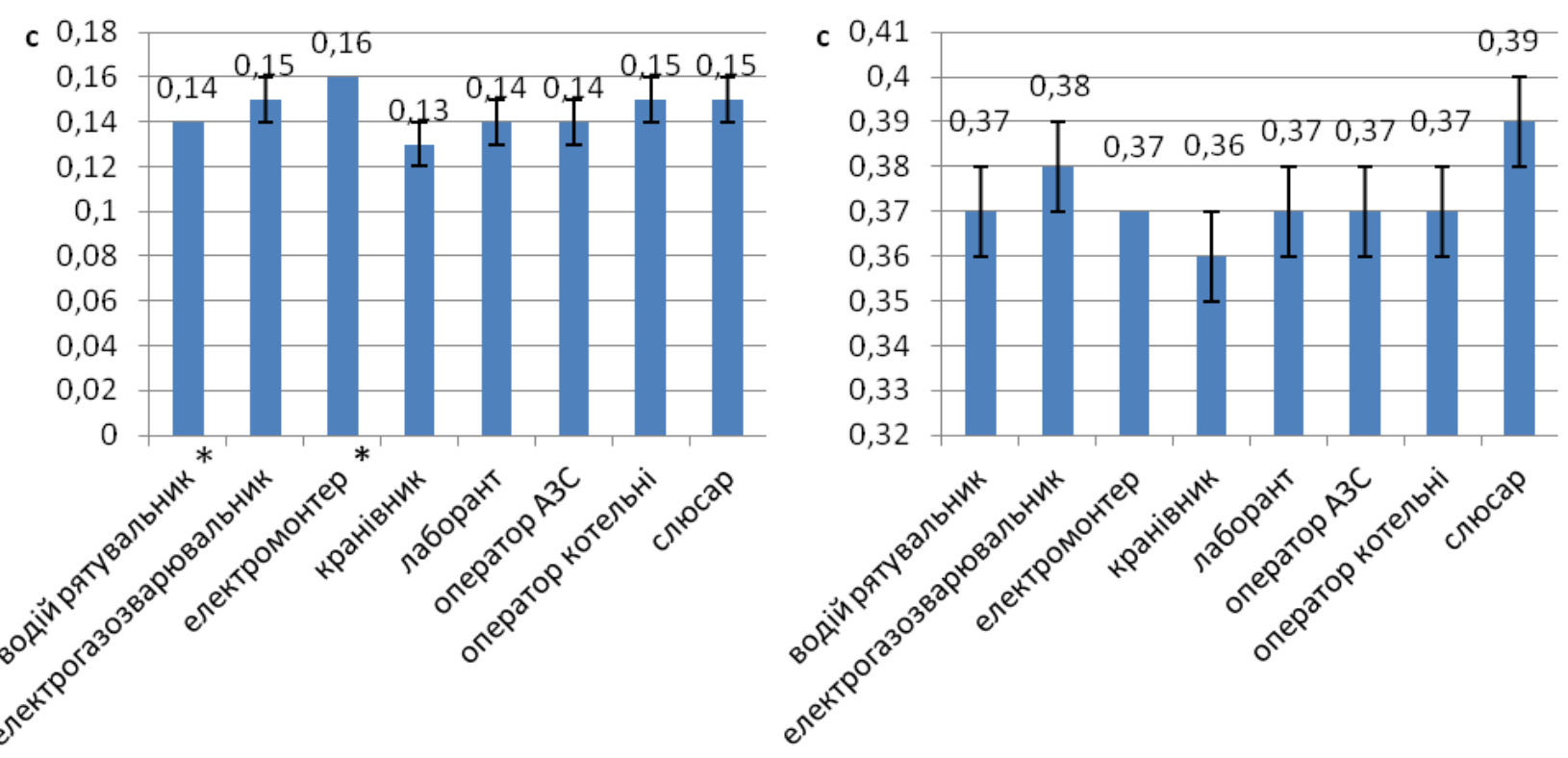

Рис. 2. Середні показники інтервалу $P Q$ (c) та $Q T$ (c)

$(13,75 \pm 0,77 \%)$, лаборантів $(12,33 \pm 2,29 \%)$ та операторів АЗС $(12,40 \pm 2,38 \%)$, порівняно 3 іншими працівниками $(\mathrm{p} \leq 0,05)$, що може свідчити про порушення ритміки роботи серця. Середні значення інтервалів PQ й QT, систолічного показника в представників різних шкідливих професій перебували в межах допустимої норми (рис. 2).

Простежено незначні відхилення від фізіологічної норми зубця Р в операторів АЗС $(0,11 \pm 0,00$ мм), вони мали найвище значення цього показника серед досліджуваних професій (рис. 3).

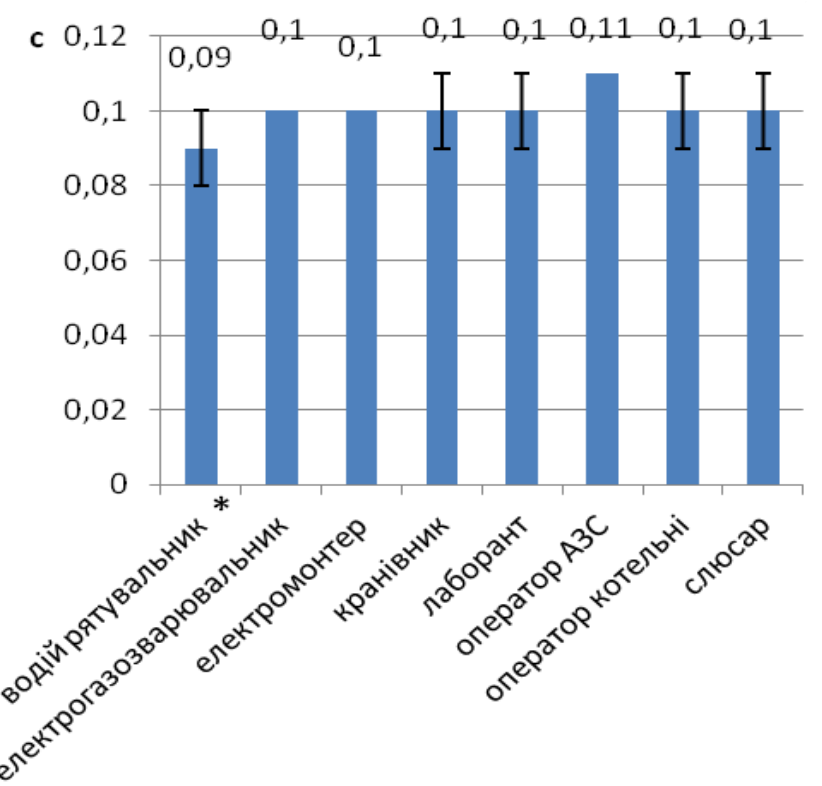

Рис. 3. Середні значення зубия Р (мм)

Останній компонент ЕКГ, який ми аналізували, - це комплекс QRS. Найвище його значення простежено в представників кількох професій, а саме: в електрогазозварювальників, електромонтерів й операторів котельні $(0,12 \pm 0,00 \quad$ c), a найнижче - лаборантів $(0,10 \pm 0,00)(\mathrm{p} \leq 0,05)$ (рис. 4).

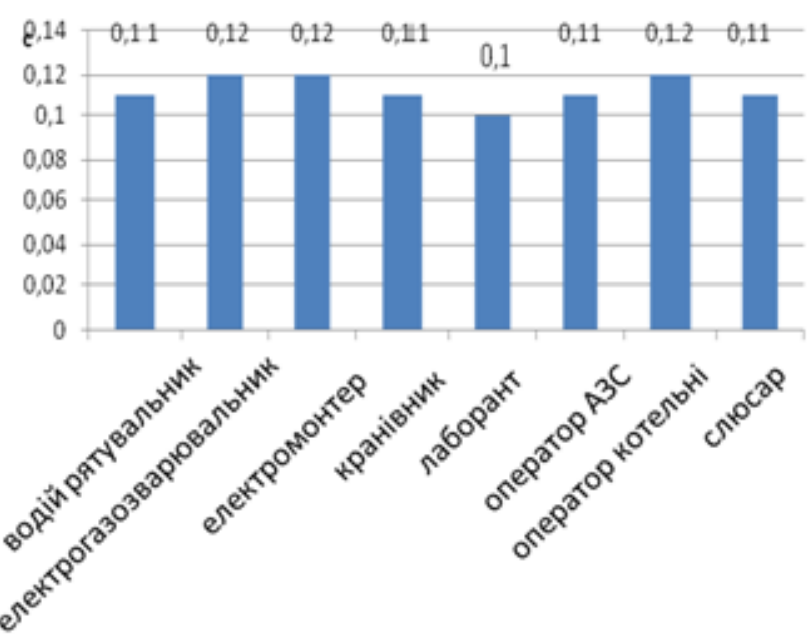

Рис. 4. Середні показники комплексу QRS (c)

За результатами аналізу ЕКГ виявилося, що найбільші відмінності спостерігали щодо величини кута $\mathrm{EBC}$, який мав значні відхилення в електромонтерів, операторів котельні й слюсарів. Також за межі фізіологічної норми виходили дані тривалості інтервалу RR в електромонтерів, лаборантів, операторів АЗС. Незначні відхилення від норми також проявлялись у значеннях зубця $\mathrm{P}$ та комплексу QRS. Можна припустити, що шкідливі умови праці негативно впливають на роботу серця й можуть провокувати різні захворювання. 
Незважаючи на те, що серцево-судинні захворювання займають провідне місце серед патологій, які спричиняють інвалідизацію або й смерть, вплив шкідливих умов праці на стан серцево судинної системи працівників недоста-тньо вивчений. Це пов'язано 3 постійним розвитком технологій, появою нового устаткування, хімічних речовин, із якими працюють люди. Недотримання санітарних норм, неналежне використання засобів захисту, недостатня профілактика та несвоєчасне лікування працівників погіршують ситуацію.

За даними [1], на представників таких професій, як електромонтери та електрогазозварювальники, шкідливо діють електромагнітні поля надвисокого діапазону. Вплив електромагнітного випромінювання на організм може спричиняти гострі інфаркти міокарда, порушення мозкового кровообігу, серцевого ритму. Шкідливими виробничими факторами $є$ вібрації, яким піддаються працівники металургійної промисловості. У кранівників, котрі працюють в умовах впливу простійної загальної вібрації, перебувають у вимушеній робочій позі, найчастіше проявляються такі серцево-судинні патології, як ішемічна й гіпертонічна хвороби серця [5].

За даними А. В. Басанець [3], шкідливі чинники виробничого середовища викликають захворювання не лише серцево-судинної системи. Ознаки серцевої недостатності проявляються під дією бензолу та іонізуючого випромінювання, гіпертрофія правого шлуночка серця - при пиловій патології легень і радіаційно-токсичному ураженні бронхіальної системи й центральних розладах кровообігу [3]. Впливу цих факторів піддаються працівники практично всіх досліджуваних нами професій. Також наведено дані про формування захворювання серцево-судинної системи при перевищенні напруженості електричного поля промислової частоти [11].

Багато працівників шкідливих професій піддаються дії свинцю, який, за [12], може викликати підвищення артеріального тиску й у деяких випадках-ішемічну хворобу серця.

C досить багато свідчень про вплив шкідливих виробничих факторів на серцевосудинну систему шахтарів. У досліджені М. Г. Ілляш та ін. [13] описано виникнення гіпертрофії міокарда, яка частіше виникає в осіб із хворобами системи кровообігу. Ексцентрична гіпертрофія лівого шлуночка достовірно частіше представлена серед шахтарів із хворобами системи кровообігу [13].

\section{Висновки}

У результаті проведеного дослідження встановлено, що шкідливі умови праці можуть більшою мірою впливати на роботу серця, водночас показники загального аналізу крові переважно перебували в межах норми. У представників різних шкідливих професій виявлено різні відхилення в ЕКГ, зокрема кут EВC мав значні відхилення в електромонтерів, операторів котельні та слюсарів. За межі фізіологічної норми виходили результати тривалості інтервалу RR в електромонтерів, лаборантів, операторів АЗС. Відхилення від норми також проявлялись у значеннях зубця $\mathrm{P}$ й комплексу QRS.

\section{Література}

1. Селюк, М. М. Вплив електромагнітних полів надвисокого діапазону на серцево-судинну систему. Артеріальна гіпертензія Українська військова академія; 2009, 5(7).

2. Глиняна, Л. А.; Родіонова, В. В.; Гашинова, К. Ю. та інші Структура промислово зумовлених захворювань у робітників металургійного підприємства, які працюють у шкідливих умовах праці. Медичні перспективи; 18, с 60-64. https://doi/orsgsnal/10.26641/2307-0404.2018.3(part 1). 142335

3. Басанець, А. В. Хвороби системи кровообігу при дії професійних факторів. Украӥнський журнал $з$ проблем медищини «Інститут медищини праџі АМН Украӥни»; 2010, 2, с 71-81.

4. WHO Mortality Database. World Health Organization, 2019, https://www.who.int/healthinfo/ mortality_data/en/.

5. Ситник, О. А. Характеристика стану серцево-судинної системи учнів молодшого шкільного віку. Педагогічні науки: теорія, історія, інноваційні технології 2013, 6(32), с 111-118.

6. Наказ Міністерства охорони здоров'я України № 246 від 21.05.2007 « Про затвердження Порядку проведення медичних оглядів працівників певних категорій».

7. Задорожня, М. Серцеві захворювання та їхні виробничі чинники. Охорона праиі $i$ пожежна безпека; 2013, 4. http://expert.fpsu.org.ua/tekhnichniminspektoram/62-certsevi-zakhvoryuvannya-ta-jikhnivirobnichi-chinniki

8. Березюк, В. С.; Лемешев, М. С. Вплив виробничого середовища на здоров'я та працездатність людини. Безпека життєдіяльності. https://web.posibnyky.vntu.edu.ua/fmbt/berezyuk_bezp eka_zhittyediyalnosti/41.htm

9. Швед, М. I. Основи практичної електрокардіографіі (навчальний посібник); Укрмедкнига: Тернопіль, 2000, 128 с.

10. Шевченко, Т. М.; Полушкін, П. М. Електронний посібник до вивчення курсу «Основи 
Показники крові та діяльності сериево-судинної системи в прачівників шкідливих професій

загальної клінічної лабораторної діагностики», Дніпропетровський національний університет ім. Олеся Гончара, 2016, 138 c. http://repository. dnu. dp. ua:1100/upload/17ba1fd9082bc67d1a6d5b0828504ea1 Osnovi_zagal'noyi_klinichnoyi_laboratornoyi_.PDF

11. Бондаренко, Є. А. Оцінка професійного ризику погіршення стану здоров'я персоналу, що обслуговує установи надвисокої напруги. Вісник Вінницького політехнічного інституту; 2013, 1, c 61-66.
12. Ghiasvand, M.; Aghakhani, K.; Salimi, A.; Kumar, R. Ischemic heart disease risk factors in lead exposed workers: research study. Journal of Occupational Medicine and Toxicology; 2013, 8.

13. Ілляш М. Г.; Андрущенко, Т. А.; Басанець, А. В.; Долінчук, Л. В. Молекулярно-генетичний аналіз гіпертрофії міокарда в шахтарів вугільних шахт України. Украӥнський кардіологічний журнал; 2014, 1, с 50-55. 